\title{
School Leaders and Inclusive Education in Peru: A Case Study of Principal Leadership in an Effective Inclusive School
}

\author{
Pamela Valdivieso \\ Officer from the Ministry of Education, Peru
}

\begin{abstract}
Since the adoption of the inclusive education (IE) approach, the Peruvian Ministry of Education has made improvements to the normative regarding special educational needs (SEN) students. However, implementing this reform continues to present numerous challenges. A recent study of the IE policy, conducted in 2016, concluded that the key problem was the lack of sensitization and low training of school leaders and teachers which prevented them from providing a better educational service to SEN students [43]. The evidence that links the role of principal leaders and IE is almost non-existent in the Peruvian context. Therefore, this qualitative case study seeks to fill this research gap by exploring the challenges, strategies, and training needs of school leaders in an inclusive school in Peru. The study was conducted in a school with a high performing school leader where it was believed that a more positive environment towards reform implementation could be found. Interview data was collected from school leaders, the administrative support staff, and teachers. The findings of this research work conclude that the selected school has been significantly successful in implementing the reform by promoting inclusive values within the school, working with the school community to improve school climate for inclusion, and developing professional learning communities to develop pedagogical strategies for inclusive teaching. This research provides important inputs for the design and implementation of leadership policies and preparation programs with attention to students with disabilities.
\end{abstract}

\section{Introduction}

Evidence from around the world reveals that the implementation of the IE reform in schools is still hindered by numerous challenges [1] [54] [47] [51] [8]. Despite the formal adoption of this approach in the legislation of many countries, its implementation is far from achieving a real and meaningful inclusion of SEN students [20].

In this regard, Peru is no exception. The National Census of 2017 showed that education amongst students over 15 with a disability, is critical. The census showed that $14 \%$ have no schooling, $32 \%$ have only reached primary level education and $30 \%$ have only reached secondary level [29]. Even more alarming are the enrolment rates amongst school-aged people with disabilities, where $40 \%$ of students between 6 and 11 years old are currently out of the school system as well as $50 \%$ in school-aged SEN students between 12 and 17 years old [28].

As such, IE remains to date as one of the biggest challenges for the Peruvian educational sector. Peru was one of the last countries in South America to adopt the IE approach in 2003 [14]. That year the General Law of Education introduced the principles of "equity" and "inclusion" in the education system, which was aimed at ensuring the integration of disadvantaged, disabled, and excluded students to school in equal access and permanency conditions [40].

In 2006, the Ministry of Education took the first steps to translate the normative into practice and launched the "Support Service and Advice for the attention of Special Educational Needs" (SAANEE) programme for this purpose. This programme was aimed at leading the process of implementation of the IE approach within mainstream schools [41]. The SAANEE programme was responsible for providing support, advice, and training to teachers and nonteaching professionals in schools; performing activities of prevention, detection, and early attention to disability; and promoting sensitization activities with the school community that involves SEN students, and their parents or guardians [42].

Nevertheless, after more than ten years of the 
SAANEE's creation, the implementation of the IE approach within mainstream schools has revealed advanced challenges. Internationally, studies [31] [16] have found school leadership and training as crucial factors lending to the performance of IE reforms. In the Peruvian context, the SAANEE original setup was mainly concerned with the detection and diagnosis of SEN students. Yet, graver gaps in pedagogical and leadership training have been revealed as missing and imperative as the next site of focus for policy systems [55].

In practice, lack of skills and knowledge, and lacking preparation for school leaders and teachers prevent them from providing better educational services to SEN students (Ministry of Education, 2016). Consequently, these policies are affecting the work of school leaders, creating an environment of low incentives for implementing and sustaining change in their schools. In fact, in many cases, school principals and teachers have a negative attitude towards the inclusion of SEN students in regular education since they feel they lack the skills necessary to meet the needs of such students. [43].

The relevance of school leadership is especially important in the Peruvian context, where the role of principals has been traditionally associated with administrative duties at school. In fact, in recent years the Ministry of Education has been promoting an education reform, designed to improve school leadership and empowering principals in their role as =pedagogical leaders [44]. Research on these lessons and findings from the first principal mentoring programme implemented by the Ministry of Education has revealed that instructional and distributed leadership training is effective for school improvement. The study also shows that principal mentoring has important positive effects in enhancing their skills to effectively support pedagogical practice, the creation of professional learning communities, and school planning [56].

Currently, there is a lack of evidence on the role of principal leadership in Peruvian schools' IE reforms. Guided by transformational, instructional, and distributed leadership theory, this study seeks to address this research gap by exploring the challenges, strategies, and training needs of school administrators on IE. The findings of this study will prove useful for future researchers and policymakers who seek to gain a more nuanced and critical understanding of the challenges facing school leaders and effective leadership practices to address SEN students' needs. It will also provide recommendations for enhancing training programme contents.

\section{Literature Review}

The publication of the No Child Left Behind has increased the pressure on school principals to be well versed in inclusionary practices [11]. Therefore, nowadays school leaders play a crucial role in the implementation of a more inclusive system [22] [17]. However, the focus of research and policies on IE has been traditionally centred on teacher training and effective teaching practice [18].

On the other hand, in the field of educational leadership, there is a significant body of studies documenting how principals influence students learning outcomes and school improvement [35] [5] [34] [38] [23] [12] [13] [49], with limited emphasis on students with disabilities [18]. It has only been in the past two decades, that researchers began to investigate the role of principals in the promotion of the inclusive reform for SEN students in schools [15] [4] [25] [37] [53] [58].

From the existing literature, the most researched leadership models that have been identified as relevant to meet the challenges of IE are "transformational" [6] [27], "distributed" [19] [32] and "instructional" leadership [24] [48]. Instructional leadership is claimed to be important to generate the link between principals and teachers to ensure that all students have access to high-quality education [50] [3]. Researchers promoting this framework state that instructional leadership is key to guiding educators as they deliver instructional programs to meet the needs of diverse students with disabilities [57]. For other authors [46] [39] [10], school leader beliefs, values, and agreement with a reform, facilitate its implementation in school [59]. The literature also suggests that fostering distributed forms of leadership through collaborative work [52] [30], community involvement, and the development of others, is relevant in the context of IE [45] [2] [7].

There is also a growing recognition in international research that one of the key factors behind the ineffectiveness of interventions attempting to make education more inclusive is the insufficient training of school leaders, who have a key role in addressing IE in schools [35] [21] [46]. The shift towards an IE paradigm in schools has created the need for the role of school leader to shift in many significant ways [33]. Esposito et.al. [21] mention at least three ways in which the role of the school leader has changed: 1 . They must be capable of fostering "equitable and socially just" inclusive schools; 2. They need sufficient knowledge on the field of "special education"; and 3. they need to know how to make the necessary curricular and pedagogical adaptations to address SEN student needs. The challenge for school leaders, is to promote collaboration amongst the 
different actors in the school community to ensure the provision of a high-quality service for all students [3]. Therefore, preparation in leadership skills and knowledge is ultimately necessary to make a difference in the services received by students with disabilities [3].

In her study "Inclusive education and the issue of change", Liasidou [36] mentions that capacitybuilding amongst school principals should be a priority in the IE reform agenda if we would like to achieve a real and sustainable change towards IE. The author stresses that one important dimension to create inclusive learning communities is to potentiate school leaders' knowledge and skills in order to implement positive changes. Similarly, Crockett [9] highlights that many times school leaders are unprepared to assist SEN students for which they should be provided with leadership skills and knowledge on special education if we want to ensure them accountable for a real change in IE.

In practice, school leadership and IE policies work separately and dissociated, while principals continue receiving training for leading mainstream schools but ignoring what are the best strategies to lead effective inclusive schools for SEN students [18]. Hence, there is an urgent need to develop evidence from practitioners' perspective that can serve as a basis for discussion regarding effective practices and potential needs for enhancing policies and procedures, from a bottom-up approach. This is especially relevant in the Latin-American context, given that the existing literature has been mainly developed in Europe and developed countries but is relatively limited for the global south [17].

\section{Research Objectives}

This study is aimed to assess the role of school leaders in implementing the IE model in a mainstream Peruvian school. This research seeks to answer the following questions:

Research question 1: What are the main challenges that school leaders face in implementing the IE model in Peruvian schools?

Research question 2: How are school leaders addressing these challenges?

Research question 3: What are the most crucial knowledge and skills that school leaders need to have for promoting inclusive leadership?

The first research question intends to delve into the main challenges that school principals face in the process of transforming and driving their schools towards an IE approach.

The second research question is aimed at understanding the strategies that school administrators perceive as effective to address the identified challenges.

The third research question is focused on leadership capacity-building that school administrators need in the context of IE.

\section{Methodology}

The assessment of the role of school leaders in implementing IE in Peruvian schools was conducted through an exploratory qualitative study undertaken in an inclusive school with top leadership practices in Peru, the "Jose Antonio Encinas" (JAE) school. The fieldwork was conducted with the participation of principals, administrative staff, and teachers. Due to the scarce literature on IE and school leadership in Peru, this study represents a seminal effort to explore this topic through a case study, which can lay the foundation for future research. The data for this study was collected through a qualitative approach comprising of interviews with the selected participants.

\section{Sampling}

The selection criteria of the inclusive school for the research was based on the results of the leadership training programme imparted by the Ministry of Education of Peru. The sample was selected from a mainstream school with SEN students whose principal had achieved the highest results in the Second Programme of Leadership Specialization, which concluded in January 2019.

As the research was centred on the role of school leaders, the sample considered stakeholders directly involved in the implementation of IE policy in the school, that is (1) the school principal and subdirector, (2) administrative support staff, and (3) teachers. Due to time limitations, the study focused on the school staff and did not include parents and the community.

\section{Data Collection Strategy}

The data collection strategy contemplated interviews with the target group. The interviews considered semi- structured questions to gather data on the following aspects: (1) challenges of working in schools that include SEN students; (2) to delve into the strategies that principals perceive are effective to create a more positive school environment to work with SEN students; (3) recommendations and suggestions on what could be improved in training programs for them to serve SEN students better and to improve supportive inclusive practices in school.

The data was collected during three visits to the 
school from 24th to 26th of July 2019, where the following activities were conducted:

- Interviews with principal and subdirector.

- Interview with administrative staff (social assistant and school administrator).

- Interviews with teachers with SEN students from primary and secondary level.

- Documentary revision of academic and psychological information of SEN Students; and school guidelines regarding IE.

Based on the transformational, instructional, and distributed leadership framework, the study considered many research indicators (Table 1) on (1) inclusive pedagogical practices, (2) inclusive values and school environment, and (3) collaborative work, to collect data on leadership challenges, strategies, and training needs.

Table 1: Research indicators

\begin{tabular}{|c|c|c|}
\hline $\begin{array}{c}\text { Research } \\
\text { Indicators } \\
\end{array}$ & \begin{tabular}{|c|} 
Research \\
instruments
\end{tabular} & Informant \\
\hline \multicolumn{3}{|c|}{ Topic 1: Inclusive Pedagogical practices } \\
\hline $\begin{array}{l}\text { - Curricular } \\
\text { adaptations } \\
\text { according to } \\
\text { SEN students' } \\
\text { needs. } \\
\text { - Monitoring or } \\
\text { mentoring of } \\
\text { teaching } \\
\text { practices and } \\
\text { addressing SEN } \\
\text { student's needs. } \\
\text { - Class } \\
\text { environment for } \\
\text { SEN students. }\end{array}$ & $\begin{array}{l}\text { - Questionnaire } \\
\text { for principal } \\
\text { and } \\
\text { subdirector. } \\
\text { - Questionnaire } \\
\text { for teachers. } \\
\text { - School } \\
\text { documentation } \\
\text { (diagnostic, } \\
\text { teacher } \\
\text { monitoring } \\
\text { plan, } \\
\text { pedagogical } \\
\text { planning } \\
\text { documentation } \\
\text { ) }\end{array}$ & $\begin{array}{l}\text { - School leaders } \\
\text { (Principal and } \\
\text { Sub-director) } \\
\text { - Sample of } 2 \\
\text { teachers (with } \\
\text { SEN students in } \\
\text { class). }\end{array}$ \\
\hline \multicolumn{3}{|c|}{ Topic 2: Inclusive values and school environment } \\
\hline $\begin{array}{l}\text { - Inclusive values } \\
\text { - School } \\
\text { environment for } \\
\text { inclusive } \\
\text { education }\end{array}$ & $\begin{array}{l}\text { - Questionnaire } \\
\text { for principal } \\
\text { and subdirector } \\
\text { - Questionnaire } \\
\text { for teachers } \\
\text { - Questionnaire } \\
\text { for school } \\
\text { administrative } \\
\text { staff }\end{array}$ & $\begin{array}{l}\text { - School leaders } \\
\text { (Principal and } \\
\text { Sub-director) } \\
\text { - Sample of } 2 \\
\text { teachers (with } \\
\text { SEN students in } \\
\text { class). } \\
\text { - Sample of } 2 \\
\text { members of } \\
\text { administrative } \\
\text { staff }\end{array}$ \\
\hline \multicolumn{3}{|c|}{ Topic 3: Collaborative work } \\
\hline $\begin{array}{l}\text { - Collaborative } \\
\text { work towards } \\
\text { addressing SEN } \\
\text { student's needs. }\end{array}$ & $\begin{array}{l}\text { - Questionnaire } \\
\text { for principal } \\
\text { - Questionnaire } \\
\text { for teachers. }\end{array}$ & $\begin{array}{l}\text { - School leaders } \\
\text { (Principal and } \\
\text { Sub-director) } \\
\text { - Sample of } 2 \\
\text { teachers (with } \\
\text { SEN students in } \\
\text { class). }\end{array}$ \\
\hline
\end{tabular}

\section{Expected outcomes}

Given that this was a first exploratory research on school leadership and IE in Peru, the research was conducted in a school with high management and leadership performance, where it was believed that a more positive environment towards inclusion could be found. This to learn from good practices and efforts to facilitate the practice of IE, as well as challenges encountered.

\section{Analysis of Findings}

The JAE school is in one of the most vulnerable areas in Lima city. It has been recognized as one of the top public schools with effective practices concerning school climate management. Additionally, in 2015, the school principal was awarded a national prize for her contribution to the country's education and development.

The JAE school became an inclusive school in 2000 when they received their first two SEN students. Nowadays, after almost 20 years of working with SEN students, the JAE school has managed to create a conducive inclusive environment for all its students. This milestone set by the JAE school has been recognized both by the local authorities and by the government, which awarded the school with the "Valora" prize only given to inclusive schools that stand out for their effective inclusionary practices.

However, the question that emerges from the JAE experience is how the school manages to create an effective inclusive environment for their SEN students? What challenges and (most importantly) what best practices can we learn from the strategies developed by school leaders to face different issues and implications of implementing IE policies? In the following analysis, these questions will be addressed.

\subsection{Challenges}

8.1.1 An initial fear of shifting to the values of IE. The transformation of the JAE school into an inclusive school was marked by an initial fear towards the change of the school team. By the time the JAE school started receiving its first SEN students during the beginning of 2000, IE was still unknown topic with no staff members having previous experience teaching SEN students. As the school community had not received any sensitization on inclusive values, the main difficulty was to change from the special education paradigm into inclusive values in the school, since most of the teachers believed that SEN students would learn better in a special school. In addition, teachers had not received previous pedagogical training on the characteristics 
of the different types of disabilities, which caused more uncertainty on how to address SEN student needs and to guide the reform in the school.

8.1.2 Improve school climate for inclusion. A second important challenge founded by the school leader to implement the IE approach in the JAE school was to eradicate the social stigmas and fears that exist among parents and students towards children with disabilities. Another emerging problem concerning school climate was the neglect of parents with SEN students about how to support their children, who received inadequate treatment at home, which affected their learning process at school. Alongside the concern with parents, the school leader had to start looking up for strategies to improve classroom climate to prevent the rising cases of bullying against SEN students from their peers.

8.1.3 Developing pedagogical strategies for inclusive teaching. One of the most challenging situations the principal of the JAE school had to face while implementing the inclusive policy was the lack of skills and training needs of teachers in matters of educational inclusion, as none of them had previous experience teaching SEN students or received specific training on IE before. In her testimony, the principal states the government does not provide training or specialization courses that allow better preparation of teachers to meet the learning needs of SEN students according to the type of disability or make curricular adaptations, thus making it difficult to find adequate pedagogical strategies to address their needs. In addition, even when the national curriculum mentions the importance of making curricular adaptations for inclusive students, it is not clear how to make these adaptations in the practice, leaving an instructional gap.

\subsection{Leadership strategies}

8.2.1 Changing the Institutional Framework to Support the Reform Within the School. One of the main factors that triggered the beginning of the reform towards IE in the JAE school was the leadership of the principal and her opening towards inclusive values. From the beginning, the principal recognized that implementing an IE reform in the JAE school required a significant change of mindset from the school community to break with the old paradigms of special education. To support this reform, the principal started advocating for a change in the institutional framework of the school, shifting towards a new management model that recognizes student diversity, that is, a system that responds to the characteristics and needs of all students.

She achieved this change in the JAE school by building up a new vision and goals in the school oriented to the promotion of inclusive values through different strategies. Firstly, from the principal experience, it was crucial to involve the school staff in the development of a new school planning system which met SEN student needs. Therefore, the promotion of school board meetings led by the principal became a useful space for the dissemination of a new vision of inclusion amongst school staff. It was during this participative and collaborative planning process that teachers and other school members agreed that a new educational approach aiming to improve education quality and equal opportunities had become a necessity for the school.

The principal also started developing evidence of SEN students' academic and professional achievements to motivate teachers and to spread a sense of pride and recognition of SEN student achievements in the school. Be it by keeping documentary records of SEN student academic achievements, diplomas, and information on the academic development of SEN students, by conducting monitoring and following up of the professional trajectories of SEN students, or by facilitating their insertion on the labour market after school, the school leader promotes an education vision that aims to ensure that all students have the same opportunities for academic and professional development.

Another important lever of change in the school was the alliances made by the principal with different institutions that were already working on IE - such as NGOs, private schools with successful experiences implementing the reform, and think tanks - to learn from the best practices to guide the JAE school towards the transformation to IE. These alliances with other civil society organizations proved to be successful and helped train teachers on pedagogical strategies for curriculum adaptation. They also proved useful for providing awareness talks and sensitization workshops with families and teachers in order to promote a transformation in school values.

As a result, distributed and transformational leadership played an important role in the dissemination of IE in the JAE school, and with it, all members of the educational community were committed and engaged in the promotion of inclusive values in the JAE school.

8.2.2 Working with school staff and community to improve school climate for inclusion. To improve the school climate for inclusion, the school leader began by promoting different sensitization 
activities in the school addressed to all parents and students (sensitization campaigns, workshops, parent's school). These activities proved effective to involved them in the inclusivity vision and to provide guidance to parents of SEN students SEN to support their children. Furthermore, the school leader started integrating SEN students in all school activities (national evaluations, school events, school competitions, etc.) to actively include them in the school community.

A second important strategy the principal deployed to face SEN student and parental neglect was to work closely with them to guide them on how to provide their children with good care at home and to make them accountable for their learning at school. The principal promoted the systematization of SEN student files, requiring information on the personal and academic background that, alongside the student academic records, could be useful for developing adequate teaching strategies according to their needs.

Likewise, the principal created the so-called "coexistence committees" for both primary and secondary levels. This committee is comprised of delegated teachers who act as observers and assure the respect of the school norms and values amongst teachers and students. The delegated teachers are trained so that they can sensitize all students and ensure respect for the SEN students, facilitating their integration in the classroom and preventing bullying problems with the arrival of a new SEN student at the school.

\subsubsection{Professional Learning Communities} (PLC) to develop pedagogical strategies for inclusive teaching. In searching for a strategy to enhance the teaching quality for SEN students, one of the effective practices that the principal promoted in the school was the development of PLC as a space for collaborative learning amongst teachers with SEN students.

PLC are organized monthly at the JAE school. The main goal of promoting this space is to research pedagogical strategies to improve teaching quality for inclusive students. These meetings are evidencebased where teachers can share their difficulties and doubts from their teaching experience with SEN students. As a result, teachers and school leaders make agreements about curricular adaptations and other pedagogical strategies to address better SEN student needs. These meetings have the following characteristics:

1. Data based driven: For these meetings, teachers use student learning data based on the results of the monitoring of teaching and learning. Thus, teachers share their knowledge to solve a problem related to the improvement of their pedagogical practice and the progress of student learning. At PLC meetings, teacher pedagogical practices are analysed to identify which aspects of the pedagogical practice should be reformulated to achieve better results among students.

2. Specific strategies are selected that allow the improvement of learning: Through reflective practice, in these meetings teachers share with their colleagues their teaching experiences of SEN students, and knowledge is generated from the feedback of teachers about the pedagogical experiences carried out in their classes. In this way, PLCs allow teachers to confront their opinions and to find original solutions that emerge from the reflection of the team.

3. Improvement agreements are established: Based on the reflections of the pedagogical practice made during the meeting, a report is prepared that is recorded in a book of minutes, and the school principal is responsible for the protection of these records. During the data collection process, these minutes were accessed, and the agreements concerning teaching SEN students were verified. Likewise, the principal points out that the commitments generated on PLC meetings are actively monitored to provide better support to teachers during the following meetings.

\section{Conclusion}

The analysis of findings shows that the JAE school has been significantly successful in implementing the IE reform. One of the key factors for achieving this transformation was the transformational, distributed, and instructional leadership displayed by school leaders.

The study found three major initial challenges to implement IE in the JAE school, which included: an initial fear of shifting to the values of IE from school staff and the community; eradicating social stigmas and neglecting SEN students; and a lack of skills and training of teachers in matters of educational inclusion.

To address these issues, the JAE school leaders conducted the following strategies: promoting inclusive values within the school, working with school staff and the community to improve school climate for inclusion, and developing PLC to enhance pedagogical strategies for inclusive teaching.

Promoting inclusive values within the school was a fundamental point to achieving an IE reform in the JAE school. This transformation towards IE implied a change in the school vision and planning, led by the school principal with the involvement and active participation of the school staff and community to be able to break with old paradigms from special 
education and persistent social stigmas towards SEN students. However, this sensitization process was also supported by external stakeholders such as the action of NGOs and other specialists involved in the reform. Therefore, another recommendation that arose from this research is that inclusive schools, through the role of the school leader, may seek to create opportunities for connections to, and collaboration with, other institutions engaged in a similar reform.

In the case of JAE school, it was equally important that leaders work collaboratively with school staff to spread the reform so that parents and the community engaged in the implementation of the IE approach. This was a critical reform the principal had to pursue to create awareness and sensitization against the many stigmas and prejudice among SEN students and to prevent bullying from the students in the classroom.

Addressing pedagogical strategies by the creation and promotion of PLC was another key strategy deployed by the JAE school principal to improve teaching practice for IE. In this sense, the PLC meetings promoted by the principal, were key to identify effective teaching strategies for SEN students and to promote effective curricular adaptations.

The study findings also reveal that one of the critical aspects in the implementation of the IE policy in the JAE school was the need to sensitize and provide better tools in practice to school principals so that they can better meet the needs of SEN students. Although the normative regulates the access of SEN students to mainstream schools since 2004 in Peru, little has been done since then to train principals and teachers in the field of IE in practice. Given the results from the study, there is a need to include a core focus on the values of IE that could be promoted through the promotion of transformational leadership on school leader training programmes.

It is pivotal that these programmes are focused on sensitizing school leaders on IE values, as well as making principals aware of the characteristics of the main types of disabilities so that they, in turn, can work more optimally on curricular adaptations in their schools. Raising awareness among principals about the values promoted by IE is of the utmost importance since school leaders are key in charge of carrying out the reform in the school.

Finally, these preliminary results show the relevance of developing further studies from a bottom-up approach to better understand the challenges and good practices which hinder effective implementation of inclusionary practices in schools.

\section{References}

[1] Ainscow, M. (2020). Inclusion and equity in education: Making sense of global challenges. Prospects, 49(3), 123134.

[2] Ainscow, M. and Sandill, A. (2010). Developing inclusive education systems: the role of organizational cultures and leadership. International Journal of Inclusive Education, Vol. 14 No. 4, pp. 401-416.

[3] Bai, H., \& Martin, S. M. (2015). Assessing the needs of training on inclusive education for public school administrators. International Journal of Inclusive Education, 19(12), 1229-1243.

[4] Billingsley, B., McLeskey, J., \& Crockett, J. (2019). Success for all students: Leading for effective inclusive schools. Handbook of leadership and administration for special education, 306-332.

[5] Bloom, Nicholas, Renata Lemos, Raffaella Sadun, and John Van Reenen (2015). Does Management Matter in Schools? The Economic Journal 125(May): 647-674.

[6] Burns, J. M. (1978). Leadership. New York, NY: Harper and Row.

[7] Bush, T., \& Glover, D. (2003). School leadership: Concepts and evidence.

[8] Chapman, C., \& Ainscow, M. (2019). Using research to promote equity within education systems: Possibilities and barriers. British Educational Research Journal, 45(5), 899917.

[9] Crockett, J. B. (2002). Special education's role in preparing responsive leaders for inclusive schools. Remedial and Special education, 23(3), 157-168.

[10] Darensbourg, K. H. (2011). The role of special education administrators in addressing contextual factors when implementing comprehensive school reform in response to the mandate of the no child left behind act of 2001 (P.L. 107-110). ProQuest LLC, 2011.

[11] Darling-Hammond, L. (1997). What Matters Most: Investing in Teaching. The School Administrator 54 (3): $44-48$.

[12] Day, C., Gu, Q., \& Sammons, P. (2016). The impact of leadership on student outcomes: How successful school leaders use transformational and instructional strategies to make a difference. Educational administration quarterly, 52(2), 221-258.

[13] Day, C., Sammons, P., \& Gorgen, K. (2020). Successful School Leadership. Education Development Trust.

[14] Defensoría del Pueblo (National Ombudsman) (2007). Educación Inclusiva: Educación para todos. Supervisión de 
la política educativa para niños y niñas con discapacidad en escuelas regulares-Lima.

[15] DeMatthews, D. (2015b). Making sense of social justice leadership: a case study of a principal's experiences to create a more inclusive school. Leadership and Policy in Schools, Vol. 14, pp. $139-166$.

[16] DeMatthews, D. E., \& Mawhinney, H. (2014). Social justice leadership and inclusion: Exploring challenges in an urban district struggling to address inequities. Educational Administration Quarterly, 50(5), 844-881

[17] DeMatthews, D. E., Kotok, S., \& Serafini, A. (2020a). Leadership preparation for special education and inclusive schools: Beliefs and recommendations from successful principals. Journal of Research on Leadership Education, 15(4), 303-329.

[18] DeMatthews, D., Billingsley, B., McLeskey, J., \& Sharma, U. (2020b). Principal leadership for students with disabilities in effective inclusive schools. Journal of Educational Administration.

[19] Dorczak, R. (2011). School Organisational Culture and Inclusive Educational Leadership. Contemporary Management Quarterly/Wspólczesne Zarzadzanie 2: 4555. https://issuu.com/ijcm/docs/2-2011. (Access date: 2 February, 2020)

[20] Duke, J., Pillay, H., Tones, M., Nickerson, J., Carrington, S., \& Ioelu, A. (2016). A case for rethinking inclusive education policy creation in developing countries. Compare: A Journal of Comparative and International Education, 46(6), 906-928.

[21] Esposito, M. K., Tang, K., \& Kulkarni, S. S. (2019). Ensuring inclusive environments for students with disabilities: School leaders play a linchpin role. Journal of Educational Administration and History, 51(1), 43-52.

[22] European Agency for Special Needs and Inclusive Education (2018). Supporting Inclusive School Leadership: Policy Review. (V. J. Donnelly, M. TurnerCmuchal and E. Óskarsdóttir, eds.). Odense, Denmark.

[23] Fryer, R. G. (2017). Management and student achievement: Evidence from a randomized field experiment (No. w23437). National Bureau of Economic Research.

[24] Goddard, R., Y. Goddard, E. S. Kim, and R. Miller (2015). A Theoretical and Empirical Analysis of the Roles of Instructional Leadership, Teacher Collaboration, and Collective Efficacy Beliefs in Support of Student Learning. American Journal of Education 121 (4): 501530 .

[25] Guzman, N. (1997). Leadership for successful inclusive schools: a study of principal behaviours. Journal of Educational Administration, Vol. 35 No. 5, pp. 439450.
[26] Hitt, D. H., \& Tucker, P. D. (2016). Systematic review of key leader practices found to influence student achievement: A unified framework. Review of Educational Research, 86, 531-569.

[27] Honingh, M., and Hooge, E. (2014). The Effect of School-Leader Support and Participation in Decision Making on Teacher Collaboration in Dutch Primary and Secondary Schools. Educational Management Administration \& Leadership 42 (1): 75-98. doi:10.1177/1741143213499256.

[28] INEI (2012). Primera encuesta nacional Especializada sobre discapacidad.

[29] INEI (2018). Perú, resultados definitivos de los censos nacionales 2017.

[30] Jones, M. and Harris, A. (2014). Principals leading successful organisational change. Journal of Organizational Change Management, Vol. 27 No. 3, pp. 473-485.

[31] Kozleski, E. (2019). System-wide leadership for culturally responsive education. In J. Crockett, B. Billingsley, \& M. L. Boscardin (Eds.), Handbook of leadership and administration for special education (pp. 180-195). New York, NY: Routledge.

[32] Kugelmass, J., and M. Ainscow (2004). Leadership for Inclusion: A Comparison of International Practices. Journal of Research in Special Educational Needs 4 (3): 133-141. doi:10.1111/J.1471-3802.2004. 00028.x.

[33] Lashley, C., \& Boscardin, M. L. (2003). Special Education Administration at a Crossroads: Availability, Licensure, and Preparation of Special Education Administrators.

[34] Leaver, C., Lemos, R., \& Scur, D. (2019). Measuring and explaining management in schools: New approaches using public data (Center for Economic Performance Discussion Paper No. 1656). Centre for Economic Performance, London School of Economics and Political Science.

[35] Leithwood, K., Harris, A., \& Hopkins, D. (2020). Seven strong claims about successful school leadership revisited. School leadership \& management, 40(1), 5-22

[36] Liasidou, A. (2015). Inclusive education and the issue of change: Theory, policy and pedagogy. Springer.

[37] Mayrowetz, D. and Weinstein, C.S. (1999). Sources of leadership for inclusive education: creating schools for all children. Educational Administration Quarterly, Vol. 35 No. 3, pp. 423-449.

[38] Mbiti, I., Muralidharan K., Romero, M., Schipper, Y., Manda, C., \& Rajani, R. (2019). Inputs, incentives, and complementarities in education: Experimental evidence from Tanzania. The Quarterly Journal of Economics, 134(3),1627-1673. 
[39] McLeskey, J., \& Waldron, N. L. (2015). Effective leadership makes schools truly inclusive. Phi Delta Kappan, 96(5), 68-73. doi:10.1177/0031721715569474.

[40] Ministerio de Educación (Ministry of Education) (2003). Reglamento de la Ley $N^{\circ} 28044$ - Ley General de Educación. http://www.minedu.gob.pe/comunicado/ normativa-desarrollo-anio-escolar-2018.php. Government of Peru. (Access Date: 31 January 31, 2021).

[41] Ministerio de Educación (Ministry of Education) (2005). Decreto Supremo N ${ }^{\circ}$ 002-2005-ED, Aprueban el Reglamento de Educación Básica Especial. Government of Peru. http://www.minedu.gob.pe/normatividad/decreto s/DS-002-2005-ED.php. (Access Date: January 31st, 2021).

[42] Ministerio de Educación (Ministry of Education) (2012). Educación Básica Especial y Educación Inclusiva - Balance y perspectivas. Dirección General de Educación Básica Especial. Government of Peru. http://www.minedu.gob.pe/minedu/archivos/a/002/05bibliografia-para-ebe/9-educacion-basica-especial-yeducacion-inclusiva-balance-y-perspectivas.pdf. (Access Date: 31 January, 2021).

[43] Ministerio de Educación (Ministry of Education) (2016). Evaluación de diseño e implementación del servicio de apoyo y asesoramiento a las necesidades educativas especiales-SAANEE. Government of Peru. $\mathrm{http} / / / \mathrm{www} . \mathrm{minedu} . \mathrm{gob} . \mathrm{pe} /$ normatividad/decretos/DS002-2005-ED.php. (Access Date: 31 January, 2021).

[44] Ministerio de Educación (Ministry of Education) (2019). Marco del Buen Desempeño del Directivo. http://www.minedu.gob.pe/normatividad/decretos/DS002-2005-ED.php. (Access Date: 31 January, 2021).

[45] Mullick, J., Deppeler, J., \& Sharma, U. (2012). Inclusive Education Reform in Primary Schools of Bangladesh: Leadership Challenges and Possible Strategies to Address the Challenges. International Journal of Whole Schooling, 8(1), 1-20.

[46] Poon-McBrayer, K. F. (2017). School leaders' dilemmas and measures to instigate changes for inclusive education in Hong Kong. Journal of Educational Change, 18(3), 295-309.

[47] Rix, J., Nind, M., Simmons, K., \& Sheehy, K. (Eds.). (2005). Policy and power in inclusive education: Values into practice. Psychology Press.

[48] Robinson, V. M. J., C. A. Lloyd, and K. J. Rowe (2008). The Impact of Leadership on Student Outcomes: An Analysis of the Differential Effects of Leadership Types. Educational Administration Quarterly 44 (5): 635674. doi:10.1177/0013161X08321509.

[49] Sammons, P., Davis, S., Day, C., \& Gu, Q. (2014). Using mixed methods to investigate school improvement and the role of leadership: An example of a longitudinal study in England. Journal of Educational Administration,
52(5), 565-589.

[50] Slater, C. L. (2012). Understanding principal leadership: An international perspective and a narrative approach. Educational Management Administration \& Leadership, 39(2), 219-227.

[51] Slee, R., \& Allan, J. (2001). Excluding the included: A reconsideration of inclusive education. International Studies in Sociology of Education, 11(2), 173-192.

[52] Spillane, J., Camburn, E. M., Pustejovsky, J., Pareja, A. S., \& Lewis, G. (2008). Taking a distributed perspective: Epistemological and methodological tradeoffs in operationalizing the leaders-plus aspects. Journal of Educational Administration, 46(2), 189-213.

[53] Theoharis, G. (2007). Social justice educational leaders and resistance: toward a theory of social justice leadership. Educational Administration Quarterly, Vol. 43 No. 2, pp. 221-258.

[54] Thomas, Gary. (2013). A Review of Thinking and Research about Inclusive Education Policy, with Suggestions for a New Kind of Inclusive Thinking. British Educational Research Journal, 39(3), 473-490.

[55] Valdivieso, P. (2018). The exclusion of the inclusive: the case of the Peruvian SAANEE programme (Unpublished master's dissertation). The London School of Economics and Political Science, London, United Kingdom.

[56] Valdivieso, P. (2021). Instructional Coaching for School Principals: Lessons and Findings from the Peruvian Principal Mentoring Programme. The Asian Conference on Education 2020, Japan. ISSN: 2186-5892.

[57] Voltz, D. L., \& Collins, L. (2010). Preparing special education administrators for inclusion in diverse, standardsbased contexts: Beyond the Council for Exceptional Children and the Interstate School Leaders Licensure Consortium. Teacher Education and Special Education, 33(1), 70-82.

[58] Waldron, N., McLeskey, J. and Redd, L. (2011). Setting the direction: the role of the principal in developing an effective, inclusive school. Journal of Special Education Leadership, Vol. 24, pp. 51-60.

[59] Wong, P. M., \& Cheung, A. C. K. (2009). Managing the process of an educational change: A study of school heads' support for Hong Kong's curriculum reform. International Journal of Educational Management, 23(1), 87-106 